\title{
Utilization of low quality roughages: effects of urea and protein supplements of differing solubility on digesta flows, intake and growth rate of cattle eating oaten chaff
}

\author{
BY R. G. REDMAN, R. C. KELLAWAY \\ AND JANE LEIBHOLZ \\ Department of Animal Husbandry, University of Sydney, \\ Camden, New South Wales 2570, Australia
}

(Received 27 June 1979 - Accepted 9 June 1980)

\begin{abstract}
I. Expt I. Five $150 \mathrm{~kg}$ steers with ruminal, abomasal and ileal cannulas were given $3000 \mathrm{~g}$ oaten chaff daily plus pelleted supplement with no added nitrogen (diet A) or $50 \mathrm{~g} \mathrm{~N} / \mathrm{d}$ as urea (diet B), casein (diet C), casein and formaldehyde-treated casein (HCHO-casein) (50:50 w/w; diet D) and HCHO-casein (diet E), in a $5 \times 5$ Latin square design. The basal diet and supplement were fed in eight equal increments at intervals of $3 \mathrm{~h}$. Proportions of dry matter and organic matter digested in the stomach and whole tract were greater for diets B, C, D and E than for diet A. Total volatile fatty acid levels in the rumen and the proportion of acetic acid were lower, and the proportion of propionic acid higher on diet $A$ than on the other diets. Rumen ammonia levels were lower on diets $\mathrm{A}, \mathrm{D}$ and $\mathrm{E}$ than on diets $\mathrm{B}$ and $\mathrm{C}$. $\mathrm{N}$ flows at the abomasum, ileum and rectum were lower on diet $A$ than on the other diets; abomasal flows and apparent intestinal absorptions of amino acids were higher on diets D and $E$ than on diets A, B and C. Efficiencies of bacterial protein synthesis were $15,15,14,13$ and $12 \mathrm{~g}$ bacterial N/kg OM truly digested in the stomach on diets A, $\mathrm{B}, \mathrm{C}, \mathrm{D}$ and $\mathrm{E}$ respectively.

2. Expt 2. Forty $300 \mathrm{~kg}$ steers were fed oaten chaff ad lib. plus twice the amount of the same pelleted supplements as in Expt I. Intake of oaten chaff was $23 \%$ higher with $\mathbf{N}$ supplements (diets B, C, D and E) than without (diet A). Live-weight gains were $356,798,843,842$ and $805 \mathrm{~g} / \mathrm{d}$ on diets A, B, C, D and E respectively.

3. It was concluded that efficiency of bacterial protein synthesis was not limited by the supply of peptides and amino acids in the rumen, and that increases in amino acid availability in the intestines from feeding HCHO-casein did not increase food intake or live-weight gain.
\end{abstract}

Peptides and amino acids contribute $200-400 \mathrm{mg} / \mathrm{g}$ nitrogen incorporated into microbial cells in the rumen (Pilgrim et al. 1970; Nolan \& Leng, 1972; Nolan et al. 1976) and in vitro studies indicated that the optimum value for non-protein- $\mathrm{N}$ to amino acid- $\mathrm{N}$ for microbial growth was 75:25 (Maeng et al. 1976). When casein replaced approximately half the $\mathrm{N}$ supplied by urea on a virtually protein-free diet fed to sheep, Hume (I970) found that there was an increased flow of microbial protein from the stomach.

These observations indicate that microbial growth in the rumen of animals eating a low protein diet may be restricted by the supply of peptides and amino acids, with a concomitant reduction in the rate of cellulose digestion in the rumen. Since the rate of digestion and retention time in the rumen are major determinants of the voluntary food intake of low quality roughages (Thornton \& Minson, 1973) it is possible that their intake may be limited by the supply of peptides and free amino acids to rumen micro-organisms.

We investigated this possiblity by supplying iso-nitrogenous amounts of urea, soluble protein (casein) or digestible by-pass protein (HCHO-casein) to steers fed oaten chaff.

\section{EXPERIMENTAL}

\section{Expt I}

Animals and management. Five Friesian steer calves were fitted with simple cannulas in the rumen, abomasum and terminal ileum at 3 months of age. At 8 months of age and 


\section{R. G. Redman, R. C. Kellaway and Jane Leibholz}

Table I. Expts I and 2. Components ( $\mathrm{g} / \mathrm{kg}$ air dry) and chemical composition ( $\mathrm{g} / \mathrm{kg}$ dry matter (DM)) of five pelleted supplements fed with oaten chaff to cattle together with daily amounts fed in the respective experiments

\begin{tabular}{|c|c|c|c|c|c|}
\hline & \multicolumn{5}{|c|}{ Supplements } \\
\hline & \multirow[b]{2}{*}{ Control } & \multirow[b]{2}{*}{ Urea } & \multicolumn{3}{|c|}{ Casein: formaldehyde-treated casein } \\
\hline & & & $100: 0$ & 50: 50 & $0: 100$ \\
\hline Diet $\ldots$ & A & B & $\mathrm{C}$ & D & $\mathbf{E}$ \\
\hline \multicolumn{6}{|l|}{ Components } \\
\hline Molasses & 406 & $36 I$ & 406 & 378 & 350 \\
\hline Oaten chaff & 197 & 175 & 197 & 183 & 180 \\
\hline Maize flour & 373 & 332 & - & - & - \\
\hline Casein & - & - & 373 & 174 & - \\
\hline Formaldehyde-treated casein & 一 & - & - & 243 & 450 \\
\hline Urea & - & II 2 & - & - & - \\
\hline Calcium stearate & 12 & ro & 12 & II & 10 \\
\hline DM & 919 & 910 & 930 & 925 & 920 \\
\hline \multicolumn{6}{|l|}{ Chemical composition } \\
\hline Nitrogen & 5.7 & $64 \cdot I$ & $66 \cdot 7$ & $71 \cdot 1$ & $72 \cdot 4$ \\
\hline Ash & 188 & 158 & $176^{\circ}$ & 175 & 154 \\
\hline$\alpha$-glucose polymers & 435 & 462 & 54 & $5 \mathrm{I}$ & 53 \\
\hline Lignin & 23 & 19 & 24 & 22 & 22 \\
\hline \multicolumn{6}{|l|}{ Amounts fed daily ( $g$ air dry) } \\
\hline Expt 1 & 336 & 378 & 336 & 360 & 387 \\
\hline Expt 2 & 670 & 754 & 670 & 720 & 776 \\
\hline
\end{tabular}

live weight $150 \mathrm{~kg}$ they were tethered in individual cages fitted with automatic feeders which delivered one-eighth portions of the daily feed at three hourly intervals.

Calves were allocated to the five dietary treatments according to a $5 \times 5$ Latin square design.

Diets and feeding procedure. The basal diet was oaten chaff containing ( $\mathrm{g} / \mathrm{kg}$ dry matter (DM)) 7.7 N, $228 \alpha$-glucose polymers, 5I ash, 47 lignin. The composition of the five pelleted supplements is given in Table I. HCHO-casein was sprayed at the rate of $100 \mathrm{~g}$ formalin solution containing $15 \mathrm{~g} \mathrm{HCHO} / \mathrm{kg}$ casein $\mathrm{DM}$, a concentration of $\mathrm{HCHO}$ selected to render the casein completely insoluble in the rumen and partly digestible in the intestines (Hemsley et al. 1973). The digestibility of the treated casein was measured in two sheep on constant daily intakes of oaten chaff by introducing $200 \mathrm{~g} / \mathrm{d}$ over $5 \mathrm{~d}$ into the rumen cannulas. Casein digestibility, calculated from the change in faecal $\mathrm{N}$ excretion before and after introducing the casein, was 0.80 . The daily intakes of diets $C, D$ and $E$ were designed to provide $250 \mathrm{~g}$ digestible casein/d. Diet $\mathrm{B}$ contained an iso-nitrogenous amount of urea and diets $A$ and $B$ contained maize flour to make them iso-energetic with the other diets. The amounts fed provided equal daily intakes of molasses, oaten chaff and calcium stearate from the five diets (Table $\mathrm{I}$ ).

In a preliminary period the five calves were given the basal diet ad lib. with pellets of diet $A$ in eight equal portions at $3 \mathrm{~h}$ intervals. Consistent intakes of $3 \mathrm{~kg}$ oaten chaff/d were recorded for all calves and intakes were kept at this level throughout the experiment. Each dietary period comprised a 2-week adjustment period followed by marker infusion over $8 \mathrm{~d}$ on the last $3 \mathrm{~d}$ of which digesta collections were made.

Marker infusions and digesta collections. Markers used were the ${ }^{51} \mathrm{Cr}$ complex of ethylenediaminetetra-acetic acid ( ${ }^{51} \mathrm{Cr}$-EDTA) (Downes \& McDonald, 1964) and ${ }^{103} \mathrm{Ru}$-labelled tris-(I, I0-phenanthroline)-ruthenium (ii) chloride ( $\left.{ }^{103} \mathrm{Ru}-\mathrm{P}\right)$ (Tan et al. I97I) and lignin. ${ }^{51} \mathrm{Cr}-\mathrm{EDTA}$ and ${ }^{103} \mathrm{Ru}-\mathrm{P}$ were infused into the rumen at the rate of $113 \mu \mathrm{Ci}{ }^{51} \mathrm{Cr}$ and 
$23 \mu \mathrm{c}{ }^{103} \mathrm{Ru}$ daily. Abomasal digesta samples were collected three times daily (0.5, I.0 and I $5 \mathrm{~h}$ respectively after three successive meals) and bulked; faecal samples were taken at the same times from the most recently voided material. Ileal digesta samples were collected once daily for $3 \mathrm{~d}$ and bulked. Digesta samples were stored at $-10^{\circ}$.

After each collection period, marker infusion was discontinued and eight samples of rumen digesta were taken during the following $30 \mathrm{~h}$. Half of each sample was acidified to $\mathrm{pH} 2$ and all samples were stored at $-10^{\circ}$.

Radioactivity measurements, chemical analyses and digesta flow calculations. Sub-samples of abomasal and ileal digesta were centrifuged at $2400 \mathrm{~g}$ for $20 \mathrm{~min}$ to obtain liquid-rich fractions and sub-samples of faeces were blended with water to form slurries. These slurry samples and samples of liquid-rich fractions and of total abomasal and ileal digesta were assayed for ${ }^{11} \mathrm{Cr}$ and ${ }^{103} \mathrm{Ru}$ in a scintillation spectrometer (Model 3320; Packard Instruments Pty Ltd, Sydney).

Total digesta and faecal samples were analysed for DM, by drying to constant weight at $80^{\circ}, \mathrm{OM}$ by ashing at $550^{\circ}$ overnight. Sub-samples of total digesta were freeze-dried before analysis for $\mathbf{N}$ by a micro-Kjeldahl technique, lignin by the method of Van Soest (1963), $\alpha$-glucose polymers by the method of Macrae \& Armstrong (1968). Total digesta samples were also analyzed for amino acids, including 2,6-diaminopimelic acid, by ionexchange chromatography using an amino acid Auto-Analyzer TSM (Technicon Instrument Corporation, Tarry Town, New York, USA) following 24 h hydrolysis in 6 m-bydrochloric acid at $136^{\circ}$ using norleucine and guanidine as internal standards; corrections were made for losses of amino acids known to occur during this hydrolysis procedure. Liquid-rich digesta fractions were analyzed for $\mathrm{DM}, \mathrm{OM}, \mathrm{N}$ and $\alpha$-glucose polymers.

Flows of abomasal, ileal and faecal digesta were calculated from the concentrations of two markers, using equations (I) (3) from Faichney (1975). ${ }^{61} \mathrm{Cr}$-EDTA was used as the liquid marker throughout. The solid phase marker was ${ }^{100} \mathrm{Ru}-\mathrm{P}$ in the first two periods and lignin in the remaining three periods; the change of marker was necessitated by the unexpectedly low specific radioactivity of ${ }^{103} \mathrm{Ru}$ in one batch of the marker. Comparisons between ${ }^{103} \mathrm{Ru}$ and lignin as solid phase markers were made with digesta samples from three animals. OM flow rates $(\mathrm{g} / \mathrm{d})$ in the three animals, based on ${ }^{100} \mathrm{Ru}$ and lignin respectively, were 1937 and 2008 , I756 and 1686 , I565 and 1672 for abomasal flows, 1536 and 1468 , 1170 and I I62, I283 and I 330 for ileal flows, and I 553 and I5I2, I I 49 and 1068, 1046 and 1000 for faecal flows.

Volatile fatty acids (VFA) in acidified rumen samples were determined by gas-liquid chromatography (F \& M Scientific 402; Hewlett Packard Australia Pty Ltd, Sydney) using 3-methyl $n$-valeric acid as an internal standard. Ammonia in acidified rumen samples was determined by the method of Chaney \& Marbach (1962). Non-acidified rumen samples were assayed for ${ }^{109} \mathrm{Ru}$ and ${ }^{51} \mathrm{Cr}$ specific radioactivities and mean retention times were calculated as the reciprocal of disappearance rate constants for the two markers.

Bacterial $N$. The proportion of abomasal $\mathbf{N}$ present as bacterial $\mathbf{N}$ was calculated as mg DAPA/g $\mathbf{N}$ in digesta $\times g$ N/mg DAPA in bacterial samples. Bacterial samples isolated from rumen fluid samples collected from each of the five steers at the end of the last collection period contained 55.9, 61.2, 53.7, $40 \cdot 9$ and $53 \cdot 7 \mathrm{mg}$ DAPA/g N on diets A, B, $C, D$ and E respectively; a mean value of $53.1 \mathrm{mg} \mathrm{DAPA} / \mathrm{g} N$ was used throughout.

\section{Expt 2}

Animals and management. Forty Hereford steers aged approximately 12 months, and weighing an average of $288 \mathrm{~kg}$ live weight were used. Animals were housed in individual stalls with sawdust bedding and water available ad lib. They were allocated to five diets 


\section{R. G. Redman, R. C. Kellaway and Jane Leibholz}

on a live-weight basis, using restricted randomization. Live weights were recorded weekly over $57 \mathrm{~d}$, and live-weight changes estimated by regressions of live weight $\nu$. time.

Diets and feeding procedure. The basal diet was the same oaten chaff as fed in Expt $I$. It was offered ad lib., accumulated food refusals being removed twice weekly. The five pelleted supplements were also the same as fed in Expt I, although larger amounts were fed (Table I) because of the higher roughage intakes of the larger animals. Daily portions of pellets were placed on top of the oaten chaff each morning, and generally eaten within I $h$.

\section{RESULTS}

Expt I

Animals remained in good health throughout the experiment, and consumed all food offered. Digesta flows of OM at the duodenum, ileum and rectum were similar for the four diets given $\mathrm{N}$ supplements (diets $\mathrm{B}, \mathrm{C}, \mathrm{D}$ and $\mathrm{E}$ ) (Table 2). On the control diet (A), faecal flows of OM were significantly greater than on the other diets; ileal and faecal flows followed the same trend but were less consistent as indicated by the larger standard errors. The proportion of abomasal flows of OM digested in the intestines tended to be lower on diets supplying soluble $\mathrm{N}$ supplements (diets $\mathrm{B}$ and $\mathrm{C}$ ). Abomasal flow of $\alpha$-glucose polymers was lower $(P<0 \cdot 10)$ on the control diet than on the four $\mathrm{N}$ diets (diets $\mathrm{B}, \mathrm{C}$, $D, E)$. Abomasal, ileal and faecal flows of $N$ were significantly lower on the control diet than on diets $B, C, D$ and $E$.

Abomasal $\mathrm{N}$ flows were $9-16 \%$ higher than $\mathrm{N}$ intakes on diets $\mathrm{B}, \mathrm{C}, \mathrm{D}$ and $\mathrm{E}$ but $70 \%$ higher on diet $\mathrm{A}$, which indicated substantial $\mathrm{N}$ re-cycling on diet $\mathrm{A}$ (Table 3). The amount of $\mathrm{N}$ apparently digested in the intestines did not differ significantly between diets. Abomasal flow of bacterial $\mathbf{N}$ and efficiency of bacterial $N$ synthesis did not differ between diets; bacterial $\mathrm{N}$ as a proportion of total abomasal $\mathrm{N}$ was significantly lower on diets $\mathrm{D}$ and $\mathrm{E}$.

Abomasal flows of most amino acids were substantially higher on diets $D$ and $E$ than on diets A, B and C, particularly proline and glutamic acid (Table 4 ). On diets B and $\mathrm{C}$, abomasal flows of amino acids were slightly higher than those on diet A. Amino acid analyses on ileal digesta samples were carried out on single pooled samples for each diet. For this reason, apparent intestinal absorptions (abomasal minus ileal flows) were not analysed statistically. Apparent intestinal absorptions of indispensable amino acids were similar on diets A, B and C, which were substantially lower than those on diets D and E. Apparent intestinal absorptions of dispensable amino acids were lowest on diets $B$ and $\mathrm{C}$, higher on diet $\mathrm{A}$ and highest on diets $\mathrm{D}$ and $\mathrm{E}$. The proportion of abomasal flow apparently absorbed was higher with indispensable than with dispensable amino acids on all treatments.

VFA concentrations in rumen fluid from diets $B, C, D$ and $E$ were significantly higher than on diet $\mathrm{A}$ and this was associated with lower proportions of acetic and higher proportions of propionic acid on diet A (Table 5). Rumen ammonia levels on diets A, D and $E$ were substantially lower than those on diets $B$ and $C$ (Table 5). Retention times for ${ }^{103} \mathrm{Ru}-\mathrm{P}$ and ${ }^{51} \mathrm{Cr}$ EDTA did not differ between treatments.

\section{Expt 2}

Animals remained in good health throughout the experiment, and readily consumed the pelleted supplements. Intakes of oaten chaff were similar for the four diets fed with $\mathrm{N}$ supplements (diets B, C, D and E) (Table 6), these intakes being an average of $23 \%$ higher than on the control diet (diet A). Live-weight gains also were similar on diets B, C, D and $\mathbf{E}$, and more than double that on $\operatorname{diet} \mathbf{A}$.

Calculated intakes of metabolizable energy (ME) were used to predict live-weight gains 


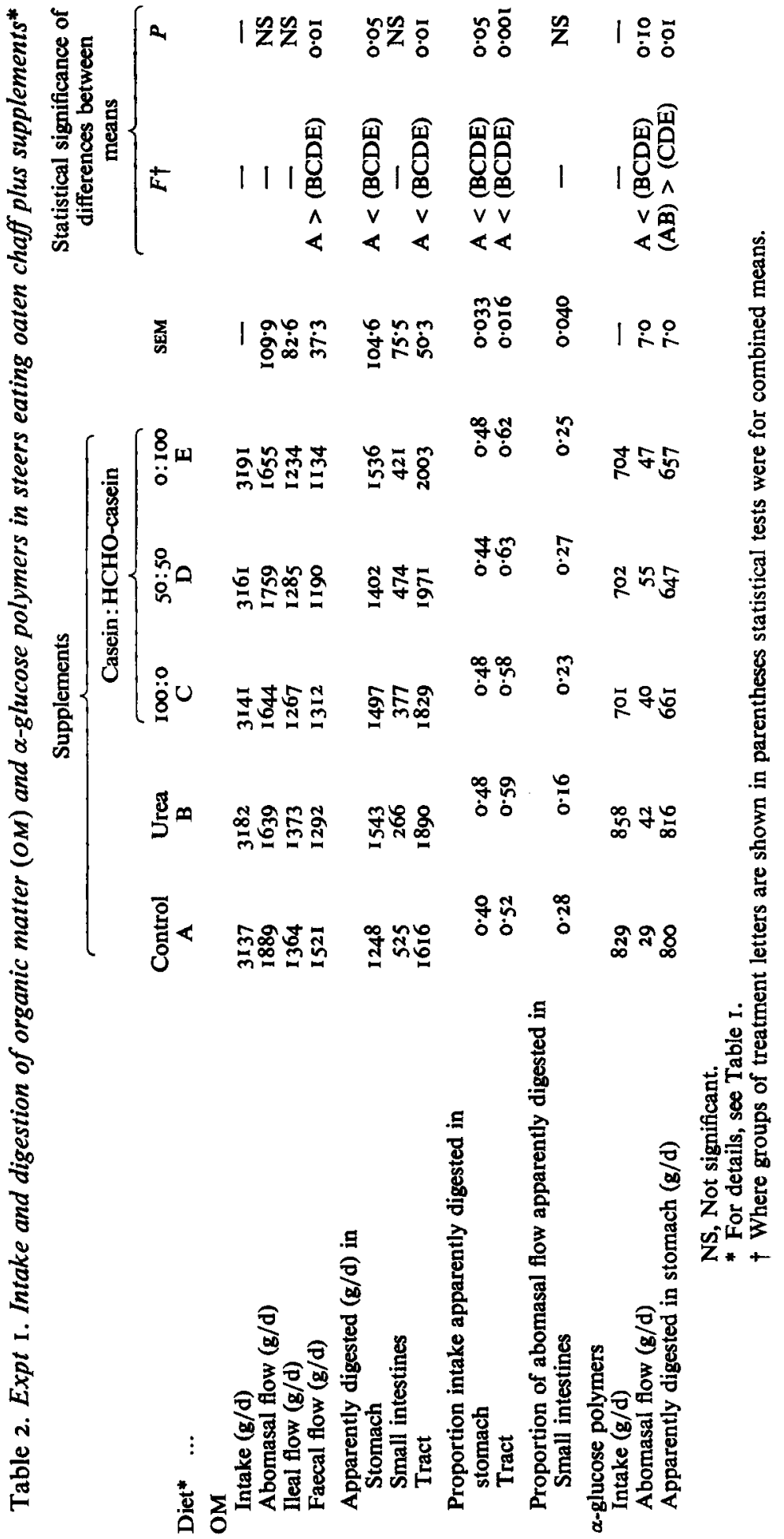


348 R. G. Redman, R. C. Kellaway and Jane Leibholz

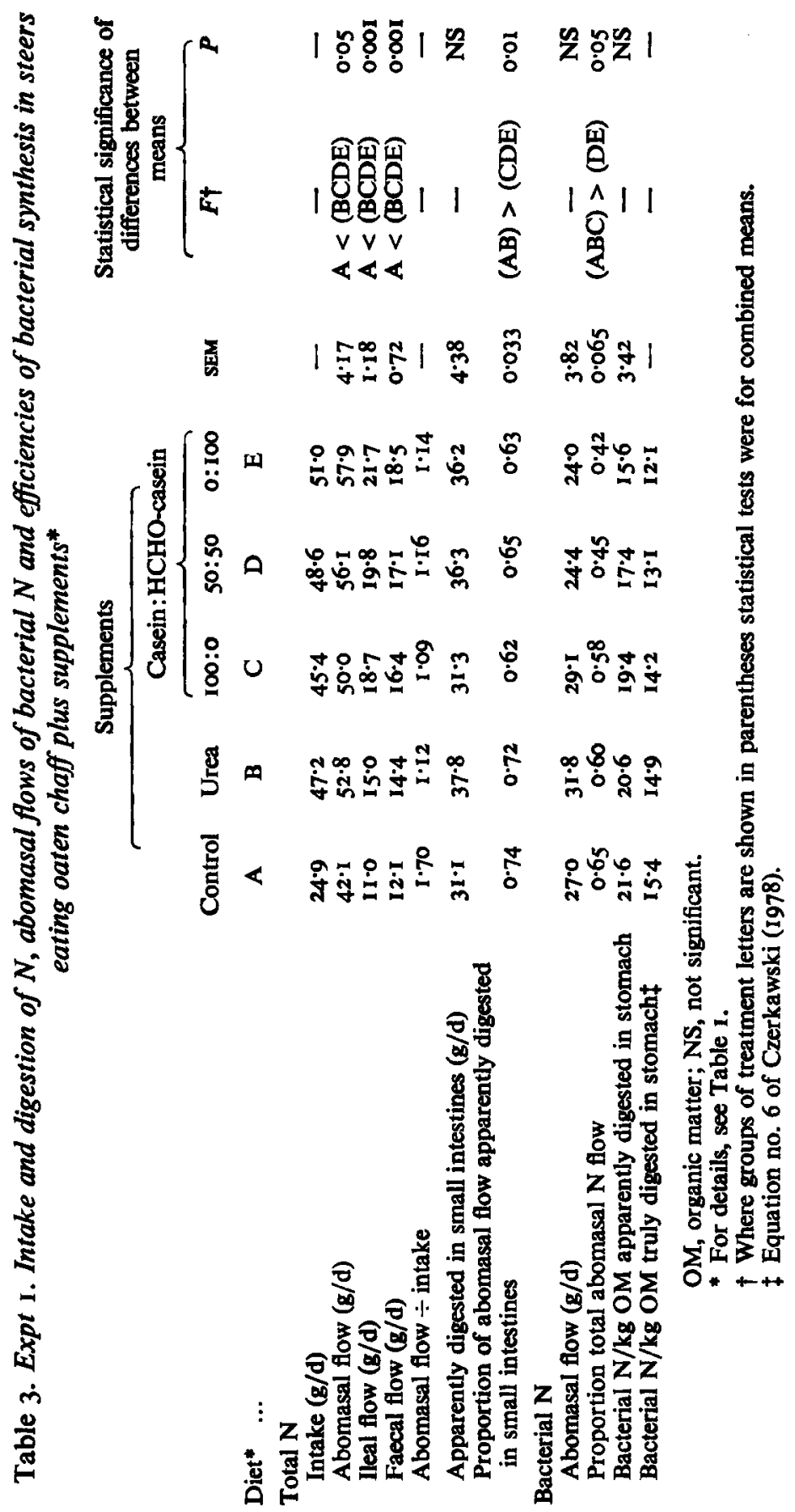


(Ministry of Agriculture, Fisheries and Food, 1975) which corresponded closely with actual gains.

\section{DISCUSSION}

\section{Expt I}

\section{Bacterial protein synthesis}

Efficiency of bacterial protein synthesis was determined when iso-nitrogenous supplements of urea, soluble protein (casein) or digestible by-pass protein (HCHO-casein) were fed at three-hourly intervals. It was assumed that casein would increase the available pool of amino acids and peptides in the rumen. When solutions of casein were introduced into the rumen of steers, protein half-lives were found to be 5.6-21.5 min (Mangan, 1972) and 65 min (Broderick, 1978). Rates of proteolysis would have been slower in our experiment because the casein was fed as dry pellets, and solubilization of casein in McDougall's (1948) buffer at $38^{\circ}$ takes approximately 12 min (R. G. Redman \& R. C. Kellaway, unpublished results). Thus, it is reasonable to assume that the supply of amino acids and peptides in the rumen was indeed greater when casein was fed than when urea was fed. However, efficiencies of bacterial protein synthesis, as indicated by abomasal flows of bacterial $\mathrm{N} / \mathrm{kg} \mathrm{OM}$ truly digested in the stomach, were similar on the control, urea and casein diets ( $15.4,14.9$ and 14.2 respectively). It appears that the supply of amino acids and peptides was not limiting bacterial protein synthesis on this diet. If $60 \%$ of bacterial $\mathrm{N}$ on the urea diet were derived from ammonia-N, $12.7 \mathrm{~g} \mathrm{~N} / \mathrm{d}$ would have been supplied from amino acids and peptides arising from proteolysis of dietary protein and endogenous secretions. Of $\mathrm{N}$ recycled to the gut anterior to the duodenum $68-77 \%$ was found to be endogenous protein rather than urea (Macrae et al. 1977). Measurements of endogenous protein in abomasal secretions (Harrop, 1974) indicate that this pathway would account for most of the endogenous protein recycled anterior to the duodenum, leaving little for secretion into the rumen. Thus, it appears that most of the amino acids and peptides in the rumen arise from dietary rather than endogenous sources. Dietary protein intake on the urea treatment was approximately $20 \mathrm{~g} / \mathrm{d}$ of which $12.7 \mathrm{~g} / \mathrm{d}$ may well have undergone proteolysis in the rumen. On semi-synthetic diets which were virtually protein-free, replacement of $100 \mathrm{mg} / \mathrm{g}$ urea $\mathrm{N}$ with casein $\mathrm{N}$ had no effect on efficiency of microbial $\mathrm{N}$ synthesis (Ben-Ghedalia et al. 1978) whereas replacement of $480 \mathrm{mg} / \mathrm{g}$ urea $\mathrm{N}$ with casein $\mathrm{N}$ increased abomasal flow of protein by $13 \%$ (Hume, 1970). This may represent an upper limit to in vivo responses to soluble dietary proteins in terms of microbial protein synthesis.

The concentration of ammonia in the rumen which promotes maximal bacterial protein synthesis is approximately $4.1 \mathrm{~mol} / 1$ (Mercer \& Annison, 1976; Okorie et al. 1977). Ammonia concentrations were lower than this on the control diet $(2 \cdot 1 \mathrm{~mol} / \mathrm{l})$ and on the treated-casein diets $(2.4$ and $2 \cdot 2 \mathrm{~mol} / 1$ on diets $\mathrm{D}$ and $\mathrm{E}$ respectively). On the control diet the low concentration of rumen ammonia was associated with a lower proportion of DM intake digested in the stomach (Table 2), a lower concentration of total VFA in the rumen and a lower value for acetic:propionic acid (Table 5) than on the other diets. Despite the lower rate of fermentation on the control diet, efficiency of bacterial growth was no lower than on other diets. DM intake was controlled at a similar level on all diets in Expt I. The more rapid rate of fermentation on all but the control diet would have facilitated higher DM intakes on these diets as indeed was found in Expt 2 (Table 6). Under these conditions it is possible that fractional outfiow rates from the rumen would have been higher, recycling of microbial $\mathrm{N}$ lower, and therefore net efficiencies of microbial protein synthesis higher.

In contrast to the control diet, low levels of rumen ammonia on the treated casein diets did not reduce the extent of OM digestion. Higher levels of rumen ammonia on the urea 


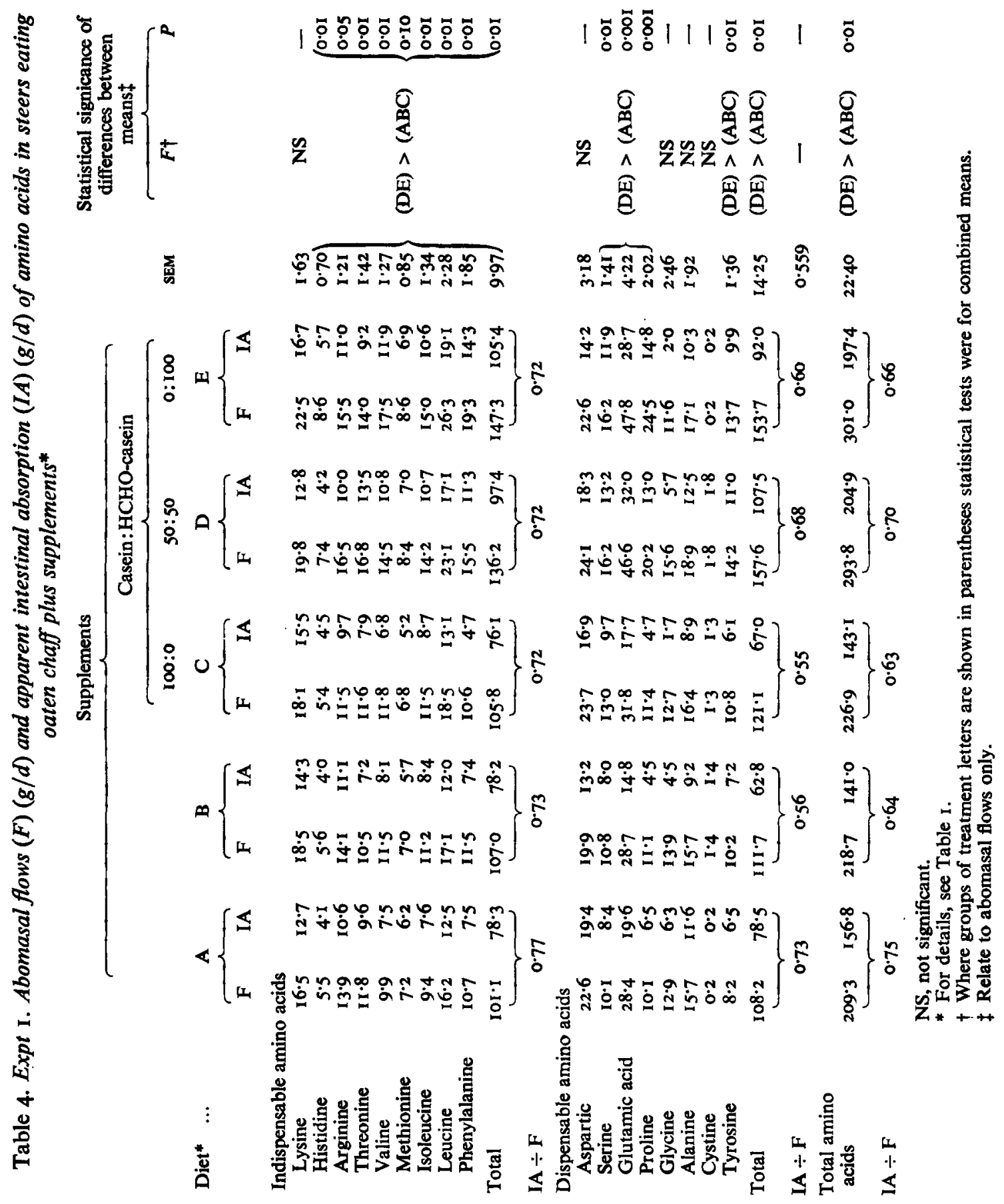


Table 5. Expt I. Concentrations of volatile fatty acids $(V F A)$ and ammonia in rumen fuid, and mean retention times of ${ }^{103} \mathrm{Ru}-\mathrm{P}$ and ${ }^{51} \mathrm{Cr}-\mathrm{EDTA}$ in the rumen of steers eating oaten chaff plus supplements*

\begin{tabular}{|c|c|c|c|c|c|c|c|c|}
\hline & \multicolumn{5}{|c|}{ Supplements } & \multirow{2}{*}{\multicolumn{3}{|c|}{$\begin{array}{c}\text { Statistical significance } \\
\text { of differences between } \\
\text { means }\end{array}$}} \\
\hline & \multirow[b]{2}{*}{ Control } & \multirow[b]{2}{*}{ Urea } & \multicolumn{3}{|c|}{ Casein:HCHO-casein } & & & \\
\hline & & & $100: 0$ & $50: 50$ & $0: 100$ & SEM & $F \dagger$ & $\boldsymbol{P}$ \\
\hline Diet* $^{*} \ldots$ & A & B & $\mathrm{C}$ & D & $\mathrm{E}$ & & & \\
\hline Total VFA (mM/l) & 61 & 79 & 78 & 78 & 73 & $5 \cdot 1$ & $A<(B C D E)$ & 0.05 \\
\hline $\begin{array}{l}\text { VFA proportions } \\
\text { Acetic } \\
\text { Propionic } \\
\text { iso-butyric } \\
n \text {-butyric } \\
\text { iso-valeric } \\
n \text {-valeric }\end{array}$ & $\begin{array}{l}0.600 \\
0.260 \\
0.031 \\
0.080 \\
0.018 \\
0.011\end{array}$ & $\begin{array}{l}0.661 \\
0.197 \\
0.027 \\
0.089 \\
0.013 \\
0.013\end{array}$ & $\begin{array}{l}0.674 \\
0.158 \\
0.026 \\
0.106 \\
0.021 \\
0.016\end{array}$ & $\begin{array}{l}0.671 \\
0.169 \\
0.031 \\
0.090 \\
0.019 \\
0.010\end{array}$ & $\begin{array}{l}0.638 \\
0.206 \\
0.031 \\
0.093 \\
0.027 \\
0.017\end{array}$ & $\begin{array}{c}0.0132 \\
0.0158 \\
= \\
= \\
=\end{array}$ & $\begin{array}{c}A<\text { (BCDE) } \\
A>\text { (BCDE) } \\
= \\
= \\
=\end{array}$ & $\begin{array}{l}0.01 \\
0.01 \\
\text { NS } \\
\text { NS } \\
\text { NS } \\
\text { NS }\end{array}$ \\
\hline Ammonia (mmol/] & 1) $2 \cdot 0$ & $5 \cdot 2$ & $5 \cdot 2$ & $2 \cdot 4$ & $2 \cdot 2$ & 0.80 & $(\mathrm{ADE})<(\mathrm{BC})$ & 0.05 \\
\hline $\begin{array}{l}\text { Mean retention tim } \\
{ }^{203} \text { Ru-P } \\
{ }^{61} \mathrm{Cr} \text { EDTA }\end{array}$ & $\begin{array}{c}\operatorname{mes}(\mathrm{h}) \\
33 \cdot 0 \\
21 \cdot 3\end{array}$ & $\begin{array}{l}31 \cdot 4 \\
22 \cdot 0\end{array}$ & $\begin{array}{l}23 \cdot 5 \\
20 \cdot 8\end{array}$ & $\begin{array}{l}\mathbf{3 8 \cdot 3} \mathbf{3} \\
\mathbf{2 8 \cdot 3}\end{array}$ & $\begin{array}{l}25.0 \\
19.4\end{array}$ & $\begin{array}{l}7.04 \\
3.45\end{array}$ & - & $\begin{array}{l}\text { NS } \\
\text { NS }\end{array}$ \\
\hline
\end{tabular}

NS, not significant.

* For details, see Table I.

$\dagger$ Where groups of treatment letters are shown in parentheses statistical tests were for combined means.

Table 6. Expt 2. Measured dry matter intakes (DMI), calculated intakes of metabolizable energy (ME) and net absorption of amino acid nitrogen ( $A A N)$, predicted and actual live-weight gains in 40 Hereford heifers eating oaten chaff plus supplements*

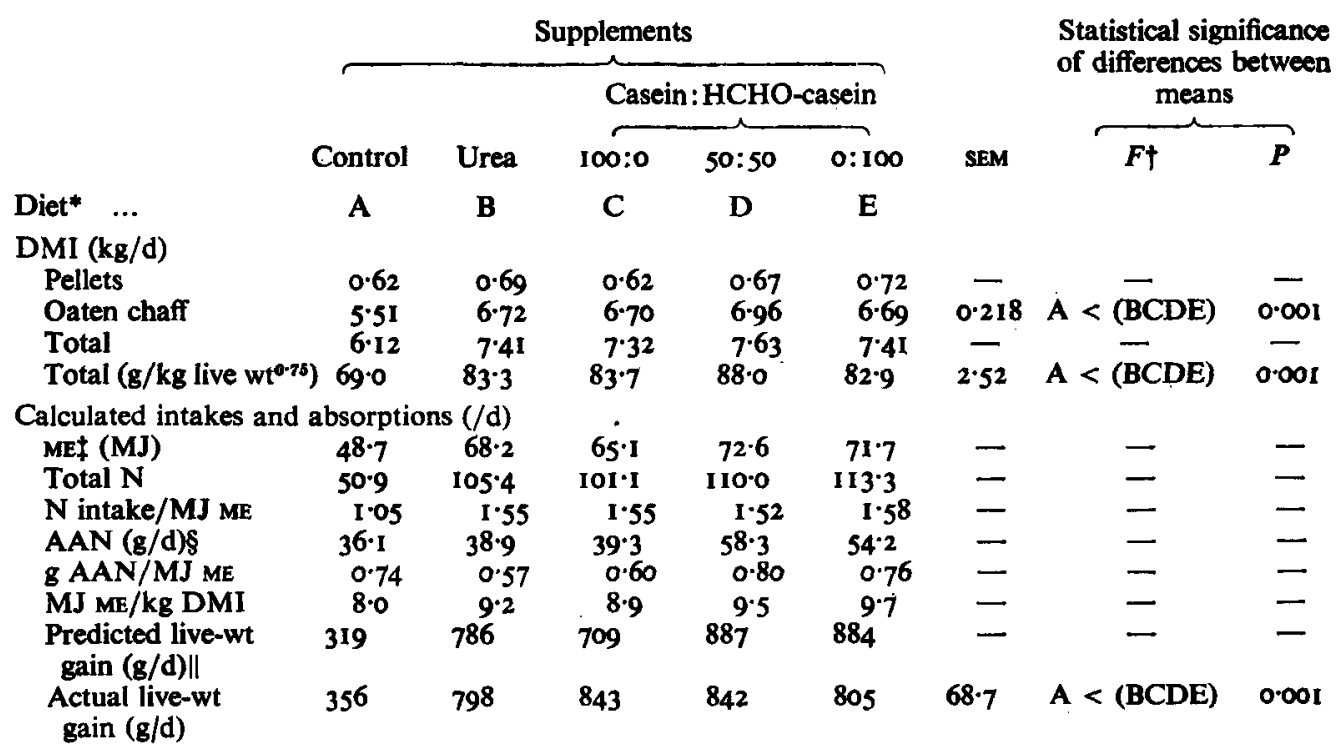

NS, not significant.

* For details, see Table I.

$\dagger$ Where groups of treatment letters are shown in parentheses statistical tests were for combined means.

$\ddagger$ Digestible organic matter in dry matter (Table 2) $\times 0.156 \times$ DMI.

8 Apparent absorption AAN/kg DMI (Tables 4 and 2) $\times$ organic matter intake $\times 0.75$ (utilization factor;

Roy et al. 1977).

If Ministry of Agriculture, Fisheries and Food (1975). 


\section{R. G. Redman, R. C. Kellaway and Jane Leibholz}

and casein diets $(5.2$ and $5.2 \mathrm{~mol} / 1$ respectively) did not facilitate greater OM digestion in the stomach than on the treated casein diets.

The range of $12-15 \mathrm{~g}$ bacterial $\mathrm{N} / \mathrm{kg}$ OM truly digested in the stomach reported here is lower than the mean of $20 \mathrm{~g}$ bacterial $\mathrm{N} / \mathrm{kg}$ OM for thirty experiments, summarized by Czerkawski ( 1978 ), in which microbial $\mathrm{N}$ was measured in terms of DAPA. However, it corresponds with efficiencies determined on similar low quality roughages (Jackson et al. I971; Kropp et al. I977). Efficiencies calculated by the same method as we used (Czerkawski, 1978) were $12-14 \mathrm{~g}$ bacterial N/ $\mathrm{kg} \mathrm{OM}$ truly digested in the rumen of steers eating lowquality grass (Kropp et al. 1977), and these were associated with low dilution rates in the rumen $(2 \cdot 1-2 \cdot 2 \% / h)$. A major factor which affects efficiency of microbial growth is rumen dilution rate, and the mean rate of $4.5 \% / \mathrm{h}$ in the present experiment (reciprocal of ${ }^{15} \mathrm{Cr}$ EDTA retention time in Table 5) is considerably lower than rates of $8-10 \% / \mathrm{h}$ which appear to be optimal (Owen \& Isaacson, 1977). A possible reason for the relatively low dilution rates in our experiment was that the diet was fed as chaffed particles $10 \mathrm{~mm}$ long. Much less mastication and rumination, and therefore saliva production, could have occurred with this material than with long roughages (Balch \& Campling, 1965).

\section{$N$ utilization}

Abomasal $\mathrm{N}$ flow was $\mathrm{I} \cdot 7$ times the $\mathrm{N}$ intake on the control diet (Table 3 ) which indicates substantial $\mathrm{N}$ recycling on this diet. Studies with ${ }^{15} \mathrm{~N}$-labelled urea indicated that only $8-18 \%$ of urea recycled to the digestive tract was degraded in the rumen (Nolan \& Leng, 1972; Nolan et al. 1976 ). Other studies with ${ }^{14} \mathrm{C}$-labelled urea found that only $23-32 \%$ of $\mathrm{N}$ added to digesta between the mouth and duodenum could be accounted for as recycled urea $\mathrm{N}$ (Macrae et al. 1977). It appears that the balance of $\mathrm{N}$ recycled anterior to the duodenum can be accounted for by abomasal secretions (Harrop, 1974). In our experiment, if it is assumed that $27 \%$ of the $\mathrm{N}$ added to digesta between the mouth and abomasum was urea, this would have added $4.6 \mathrm{~g}$ urea-N/d to the rumen $\mathrm{N}$ pool, which is a relatively small proportion of the $\mathrm{N}$ intake of $25 \mathrm{~g} / \mathrm{d}$ on the control diet. Indeed $\mathrm{N}$ was limiting the rate of fermentation on this diet as shown by the substantial increase in rumen fermentation when dietary $\mathrm{N}$ supplements were given.

$\mathrm{N}$ digestibility in the intestines was influenced by the microbial $\mathrm{N}$ : casein- $\mathrm{N}$ value. On diets $A$ and $B$ where bacterial $N$ was 0.65 and 0.60 of abomasal $N$, apparent $N$ digestibilities were 0.74 and 0.72 respectively, whereas on diets $\mathrm{D}$ and $\mathrm{E}$ where bacterial $\mathrm{N}$ was 0.45 and 0.42 of abomasal $N$, apparent $N$ digestibilities were 0.65 and 0.63 respectively (Table 3). The relatively low digestibility of HCHO-treated casein in diets D and E was partly anticipated from the preliminary in vivo test which showed that the digestibility of treated casein between the rumen and rectum was 0.80 . We attempted to compensate for this by feeding proportionately more $\mathrm{N}$ in diets $\mathrm{D}$ and $\mathrm{E}$.

Mean abomasal flows and mean apparent intestinal absorptions of amino acids were 36 and $37 \%$ higher respectively on diets $\mathrm{D}$ and $\mathrm{E}$ than on diets $\mathrm{A}, \mathrm{B}$ and $\mathrm{C}$. The proportions of glutamic acid and proline in abomasal digesta and apparently absorbed amino acids were greater on diets $D$ and $E$ than on diets $A, B$ and $C$. This is related to the higher concentration of these amino acids in casein than in bacteria and confirms observations made by Faichney (1974), Sharma et al. (1974) and Williams \& Smith (1976).

\section{Expt 2}

\section{Production responses to $N$ supplements}

Intakes of oaten chaff with diets receiving $N$ supplements were $21-26 \%$ higher than on the control diet (Table 6). $\mathrm{N}$ intake/MJ ME was $\mathrm{I} \cdot 05$ on the control diet, which is con- 
siderably less than the value of $\mathbf{I} \cdot 25$ adopted as a desirable value for rumen degradable $\mathbf{N}$ (RDN):ME intake (Roy et al. 1977). The consequences of low availability of RDN are reductions in digestibility and rate of passage (Campling et al. 1962). We found that in Expt I digestibility and rumen VFA levels were lowest on the control diet. It is likely that rate of passage was also lowest on this treatment and that this would have been a major factor limiting intake. $\mathrm{N}$ intake/MJ ME was in excess of $\mathrm{r} \cdot 5$ on all other treatments.

The substantial intake responses to urea in our experiment are similar to those reported by Campling et al. (I962) for oat straw. In our experiment $26 \%$ of DM intake was $\alpha$-glucose polymers of which one-third came from maize flour in the pellets and two-thirds from grain in the oaten chaff. It is possible that this highly-fermentable substrate enhanced efficiency of urea utilization as suggested by Egan (1975). However, Campling et al. (I962), Hemsley \& Moir (1963) and Faichney (1965) all showed that addition of sucrose did not enhance urea utilization on straw diets. In contrast, Hennessy et al. (1978) found that intra-ruminal infusion of molasses (which avoids the palatability factor) increased considerably the effects of urea alone on digestibility and intakes of native pasture hay. Synergistic effects on intake of feeding highly fermentable substrates with urea are often confounded with palatability of the substrate. It would be useful to differentiate between effects of highly fermentable substrates on intake and rumen fermentation of low quality roughages supplemented with urea.

All $\mathbf{N}$ supplements fed in Expt 2 increased intake of oaten chaff to the same extent as urea. If abomasal flows of amino acids were indeed higher on HCHO-casein diets than on the other diets, as calculated in Table 6, there were no stimulatory effects on intake such as those reported by Egan (1975). The value for $\mathrm{g}$ digestible protein:MJ digestible energy (DE) below which duodenal infusion of casein increased voluntary intake in Egan's (1975) experiments with sheep was approximately 6.0. In Expt 2 it can be calculated from values in Table 6 that there were $5 \cdot 7,4 \cdot 9,5 \cdot 8,7 \cdot 2$ and $6 \cdot 7 \mathrm{~g}$ digestible protein:MJ DE on diets $A, B, C, D$ and $E$ respectively. This may be interpreted to indicate that these animals should have increased their intake in response to the greater protein:energy on diets $D$ and $E$. In fact they did not respond to the greater protein : energy, but did give a substantial response to urea- $\mathrm{N}$ which actually reduced the protein:energy ratio (4.9 on diet $\mathrm{B}$ ). It is possible that the disparity between our results and those of Egan (1975) is due to species differences. The lowest voluntary intake per $\mathrm{kg}$ live-weight $\mathrm{t}^{\circ} \mathbf{7 5}$ in our experiment was about double that in Egan's (1975) experiments, which conforms with observations of Playne (1970) that voluntary intake of low quality roughages per unit metabolic size is much greater for cattle than for sheep.

Predicted live-weight gains were very similar to actual live-weight gains which indicates that live-weight responses to $\mathrm{N}$ supplements can be explained entirely in terms of intake. The calculated values for amino acid $\mathbf{N}$ absorbed:MJ ME intake were all well in excess of requirements given by $\varnothing$ rskov (1977), and differences between treatments did not give rise to differences in efficiencies of energy utilization.

The authors wish to thank Professor E. F. Annison for helpful discussions throughout the project. They are very grateful to $\mathrm{Mr}$ C. Stimson and Mr R. Butchers for technical assistance. This study was supported financially by the Australian Meat Research Committee.

\section{REFERENCES}

Balch, C. C. \& Campling, R. C. (1965). In Physiology of Digestion and Metabolism in the Ruminant, p. 108 [R. W. Dougherty, editor]. London: Butterworths.

Ben-Ghedalia, D., McMeniman, N. P. \& Armstrong, D. G. (1978). Br. J. Nutr. 39, 37.

Broderick, G. A. (1978). J. Nutr. 108, 181 . 


\section{R. G. Redman, R. C. Kellaway and Jane Leibholz}

Campling, R. C., Freer, M. \& Balch, C. C. (1962). Br. J. Nutr. r6, I 15.

Chaney, A. L. \& Marbach, E. P. (I962). Clin. Chem. 8, I 30.

Czerkawski, J. W. (1978). J. Dairy Sci. 6r, 26r.

Downes, A. M. \& McDonald, 1. W. (1964). Br. J. Nutr. I8, I 53.

Egan, A. G. (1975). Rev. Rur. Sci. 2, 135.

Faichney, G. J. (I965). Aust. J. agric. Res. 16, I59.

Faichney, G. J. (1974). Aust. J. agric. Res. 25, 583.

Faichney, G. J. (1975). In Digestion and Metabolism in the Ruminant, p. 277 [I. W. McDonald and A. C. I. Warner, editors]. Armidale: University of New England Printing Unit.

Harrop, C. J. F. (1974). J. agric. Sci., Camb. 83, 249.

Hemsley, J. A. \& Moir, R. J. (I963). Aust. J. agric. Res. I4, 509.

Hemsley, J. A., Reis, P. J. \& Downes, A. M. (1973). Aust. J. biol. Sci. 26, 961.

Hennessy, D. W., Nolan, J. V., Norton, B. W., Ball, F. M. \& Leng, R. A. (1978). Aust. J. exp. Agric. Anim. Husb. $18,477$.

Hume, I. D. (1970). Aust. J. agric. Res. 21, 305.

Jackson, P., Rook, J. A. F. \& Towers, K. G. (1971). Proc. Nutr. Soc. 30, IA.

Kropp, J. R., Johnson, R. R., Males, J. R. \& Owen, F. N. (1977). J. Anim. Sci. 46, 844.

McDougall, E. I. (1948). Biochem. J. 43, 99.

Macrae, J. C. \& Armstrong, D. G. (1968). J. Sci. Fd Agric. r9, 578.

Macrae, J. C., Wilson, S., Milne, J. A. \& Spence, A. M. (1977). Proc. Nutr. Soc. 36, 77 A.

Maeng, W. J., Van Nevet, C. J., Baldwin, R. L. \& Morris, J. G. (I976). J. Dairy Sci. 59, 68.

Mangan, J. L. (1972). Br. J. Nutr. 27, 26I.

Mercer, J. R. \& Annison, E. F. (1976). In Protein Metabolism and Nutrition, p. 397 [D. J. A. Cole, K. N. Boorman, P. J. Buttery, D. Lewis, R. J. Neale and H. Swan, editors]. London: Butterworths.

Ministry of Agriculture, Fisheries and Food (1975). Tech. Bull. Min. Agric. Fish. Fd no. 33.

Nolan, J. V. \& Leng, R. A. (1972). Br. J. Nutr. 27, 177.

Nolan, J. V., Norton, B. W. \& Leng, R. A. (1976). Br. J. Nutr. 35, I 27.

Okorie, A. V., Buttery, P. J. \& Lewis, D. (1977). Proc. Nutr. Soc. 36, 38A.

Ørskov, E. R. (1977). Wld Rev. Nutr. Diet. 26, 225.

Owen, F. N. \& Isaacson, H. R. (1977). Fedn Proc. Fedn Am. Socs exp. Biol. 36, 198.

Pilgrim, A. F., Gray, F. V., Weller, R. A. \& Belling, C. B. (1970). Br. J. Nutr. 24, 589.

Playne, M. J. (1970). Proc. Aust. Soc. Anim. Prod. 8, 511.

Roy, J. H. B., Balch, C. C., Miller, E. L., Ørskov, E. R. \& Smith, R. H. (1977). Proc. 2nd int. Symp. Protein Metabolism and Nutrition, The Netherlands, p. 126.

Sharma, H. R., Ingalls, J. R. \& Parker, R. J. (1974). Can. J. Anim. Sci. 54, 305.

Tan, N. H., Weston, R. H. \& Hogan, J. P. (197I). Int. J. appl. Radiat. Isot. 22, 301.

Thornton, R. F. \& Minson, D. J. (I973). Aust. J. agric. Res. $24,889$.

Van Soest, P. J. (1963). J. Ass. off. agric. Chem. 46, 829.

Williams, A. P. \& Smith, R. H. (1976). Br. J. Nutr. 36, 199. 